the L.C.C.) as guest speaker. Much depends upon the question master, who introduces the speakers, and generally 'controls' his team. Questions are invited from the public, and an average number of about thirty are sent in for each meeting. It has been found that a good panel can deal with about ten questions in an hour, so the Committee gives careful consideration to selecting those questions which cover the most ground and provide the greatest variety. The audience particularly appreciates an opportunity of submitting written supplementary questions. Stewards (provided with pencils and paper) collect these during the session, and the last twenty minutes are devoted to dealing with them in a brisk 'sharp-shooting' fashion. One important feature of the Nottingham Open Forum is that the members of the panel meet for a few minutes before the public proceedings begin, when they are given a list of the questions. This avoids any confusion as to who shall answer each question first, and provides an opportunity for the speakers to decide.when they can best make their own special contributions, while in no way destroying the spontaneity of their answers. The Open Forum has attracted an audience of from three hundred to four hundred at each meeting, and the enthusiasm shown has been gratifying. Especial appreciation has been expressed by foreign nationals from the occupied countries who are much impressed by the 'free speech' permissible in Great Britain. Further information can be obtained from the Secretary of the Nottingham Open Forum, Mrs. R. B. Calder, 5 Western Terrace, The Park, Nottingham.

\section{Charles L. Mayer Awards for Animal Cell Growth Research}

Dr. Wiltram J. RobBIns, chairman of the National Science Fund of the U.S. National Academy of Sciences, has announced the creation of two 2,000 dollars prizes to be known as the Charles L. Mayer Awards and to be presented in 1942 and 1943 for outstanding contributions to our knowledge of factors affecting the growth of animal cells with particular reference to human cancer. The awards are to be. not only in recognition of past accomplishments but are also designed to increase the opportunities of those with exceptional abilities to carry on further research. To assist the National Seience Fund in effective administration of the Mayer Awards, a special advisory committee has been appointed consisting of Dr. R. R. Williams, chemical director of the Bell Telephone Laboratories, Dr. Alan Gregg, director for the Medical Sciences of the Rockefeller Foundation, Dr. George H. Whipple, dean of the School of Medicine and Dentistry of the University of Rochester, and Dr. Elihu Root, jun., as the lay member. The donor of the Charles L. Mayer Awards, Dr.' Robins said, had in mind the vast possibilities offered by research on the action of chemical agents and physical factors in stimulating or retarding cell growth, and the National Science Fund would consider studies of factors controlling the growth of protozoa, of animal tissue cultures or of entire organisms as eligible.

In announcing the establishment of these Awards, Dr. Robbins directed attention to significant work which has been done on the amino-acids and some of the more recent discoveries on the importance of the rarer mineral elements, for example, manganese and copper, as necessary for animal cell development.
Recent advances in the identification and isolation of some of the vitamins and hormones have opened new vistas for the student concerned with the control of growth. Along with the increased knowledge of factors stimulating growth there have been significant contributions to our information about growthinhibitors such as the sulpha drugs and the antivitamins. Dr. Robbins emphasized that the Committee is interested primarily in fundamental studies on the factors influencing growth of animal cells rather than applications to any particular aspect of normal or abnormal growth. Applications based on such studies may develop in the future but at present we need more knowledge of the essentials concerned. Reports of empirical success in treatment of human cancer will not be eligible for the awards. The Advisory Committee will welcome suggestions at once as to outstanding published contributions and manuscripts of 1942 on any phase of this subject, at the National Science Fund olfices, 515 Madison Avenue, New York City.

\section{National Coal Board}

AT the first meeting of the National Coal Board held on December 21, Major the Right Hon. Gwilym Lloyd George, Minister of Fuel and Power, presided. $\mathrm{He}$ pointed out that the establishment of the Board completes the final stage in the Government's plan for the war-time reorganization of the industry in Great Britain. The Board would advise the Minister, in whose hands control of the industry is vested, and he appealed to members of the Board to approach the problems with which they would deal from a national point of view, and on the basis of national service. Sub-committees were appointed for dealing with the following matters : (1) The general planning of production, including the allocation of district and regional targets. The best means of securing the highest efficiency of the coal-mining industry and any improvements in machinery or methods of operation whereby output may be increased. (2) The provision of supplies, equipment and materials for the conduct of mining operations. (3) Matters relating to the maintenance of man-power and labour productivity, including the enrolment of now entrants and the instruction, training and advancement of boys and youths. (4) All matters affecting the welfare of mineworkers, including housing, transport and feeding facilities; and questions of health and safety and, in particular, such occupational diseases as silicosis and nystagmus, with the view of providing all possible preventive measures, clinical treatment and rehabilitation.

\section{The Turkish Earthquakes}

Ever since the great Turkish earthquakes of December 27, 1939 (NATURE, 145, 13; 1940), it has been noted that the earth-blocks in the affected district have never really attained their final position of rest. Aftershocks of the 1939 earthquake were frequent, of considerable amplitude and protracted. These followed the normal course, consisting of large shocks of gradually decreasing severity, interspersed with numerous minor shocks and tremors. Aftershocks, however, normally finish some months after their 'parent' shock and subsequent earthquakes with adjacent epicentres must be regarded as discrete. As recently as December last (NATURE, 150, 687 ; 1942) renewed seismic activity in Anatolia was noted. 